\title{
Smart biofilms produced from fish filleting wastes
}

\author{
R.S. Brito, C.A. Araújo \& L.F.H. Lourenço \\ Faculty of Food Engineering, Federal University of Pará, Pará, Brazil \\ E.J.G. Pino-Hernádez \& G.S. Souza Matos \\ Centre for Biological Engineering, University of Minho, Minho, Portugal \\ M.R.S. Peixoto Joele \\ Federal Institute of Education, Science and Technology of Pará, Pará, Brazil
}

\begin{abstract}
The myofibrillar proteins utilization from fish processing wastes to produce films has an importance to decrease the environmental impact due to usual inappropriate disposal of these wastes. The aim of this work was to make and characterize biodegradable films developed from myofibrillar proteins of gó whitefish (Macrodon ancylodon) wastes, with anthocyanin addition as a $\mathrm{pH}$ change indicator. The material proteic extracted was chacterized presenting high concentration of total proteins $(95.01 \%)$, important for the development of filmogenic solution. According to the results, there was a significant difference $(p<0.05)$ between the control and the added with anthocyanin biofilms. The film with lower concentration of anthocyanin presented better barrier property, with water vapor permeability of $3.8 \times 10^{-11} \mathrm{~g} \cdot \mathrm{m}^{-1} \cdot \mathrm{s}^{-1} \cdot \mathrm{Pa}^{-1}$. There is a great potential for fish processing wastes utilization to obtain biodegradable films even as the anthocyanin pigment powder is promising to act as $\mathrm{pH}$ indicator.
\end{abstract}

\section{INTRODUCTION}

The fishing industry during the processing generates a volume of waste higher than $50 \%$ (Gonçalves, 2011; Balbinot, 2015), which by-products of fish filleting (flour, surimi, for example) are compound by high levels of proteins, requiring a better use of this raw material. There are three types of proteins in fish: sarcoplasmic, stromal and myofibrillar (Dangaran et al. 2009) and among them myofibrillar proteins extracted from the fish muscles have been used as film-forming material by several researchers (Iwata et al. 2000; Paschoalick et al. 2003; Shiku et al. 2003, 2004; Artharn et al. 2007).

The large environmental impact generate from waste disposal of non-biodegradable plastic materials has become a global concern. Therefore, to partially replace this type of material, researches are being done to find or to develop ecological and renewable polymer materials (Khwaldia et al. 2010). In this context, the development of biofilms with characteristics of biodegradable packaging has become a priority because it contributes to the reduction of environmental problems caused by the constant use of petroleum-based polymers (Davanço et al. 2007; Arrieta et al. 2014).

Biodegradable films obtained from biological materials act as a barrier to external elements, protecting packaged products from physical and biological damage, preventing the volatilization of compounds and moisture loss, increasing the shelf life of the product. Recent studies have demonstrated that myofibrillar proteins have excellent ability to form biofilms, specifically those of fish (Arfat et al. 2014) and beef (Souza et al. 2012).

There are different types of smart packaging, among them those that indicate the $\mathrm{pH}$ change in the food for the consumer, by color change of the pigments present in the packaging material that are sensitive to $\mathrm{pH}$ alterations (Rebello, 2009). According to Bridle 
and Timberlake (1997), the largest group of water-soluble pigments in the Plant Kingdom are anthocyanins, which are studied all over the world as natural coloring agents in foods, responsible for the tones ranging from red to blue. The properties of anthocyanins, including their color, are strongly influenced by their structure and $\mathrm{pH}$ (Lopes et al. 2007).

Therefore, the aim of this work was to develop a smart biodegradable film from fish proteins added with anthocyanins and evaluate the film change color according to $\mathrm{pH}$ of the packaged product.

\section{MATERIAL AND METHODS}

\subsection{Material}

The gó whitefish (Macrodon ancylodon) wastes were obtained from fish filleting processing of fishing industry Ecomar, located in Vigia City (Pará State-Brazil). The natural powdered anthocyanin was obtained from the Centro de Valorização Agroalimentar dos Compostos Bioativos da Amazônia (CVACBA).

\subsection{Extraction of myofibrillar proteins}

The methodology proposed by Limpan et al. (2010) was used with some modifications, according to the Figure 1. The proteic material extracted was characterized by analysis of protein, ash, moisture and lipids performed according to AOAC method (2000).

\subsection{Development of smart biodegradable films}

The biofilms were developed according to Limpan et al. (2010) and Arenas (2012), with modifications. To obtain the filmogenic solution was mixed $1 \%$ of lyophilized myofibrillar proteins with distilled water and $40 \%$ of glycerol as plasticizer. The $\mathrm{pH}$ was adjusted to 3 with hydrochloric acid $2 \mathrm{M}$ and the solution was homogenized under $10000 \mathrm{rpm}$ for 5 minutes using homogenizer Turratec (Tecnal, TE-102). Then, the solution was heated in a water bath (Tecnal, TE-057) for 30 minutes at $60^{\circ} \mathrm{C}$, under manual stirring with glass rod for better heat distribution. After cooling, 7 (seven) portions of the solution were separated, in 6 (six) was added natural anthocyanin at concentrations ranging from 0.05 to $0.1 \mathrm{~g}$ anthocyanin/ $100 \mathrm{~g}$ of filmogenic solution, and 1 (one) was the control solution (without addition of anthocyanin).

According to casting method González et al. (2017) with some modifications, $130 \mathrm{~mL}$ of filmogenic solution was added in silicone support $(22 \mathrm{~cm}$ in diameter $\times 3 \mathrm{~cm}$ in height) and dried in incubator stove (Quimis, Q315M) for 16 hours at $25^{\circ} \mathrm{C}$. After drying, the biofilms were stored in polyethylene packaging at room temperature $\left(22^{\circ} \mathrm{C}\right)$.

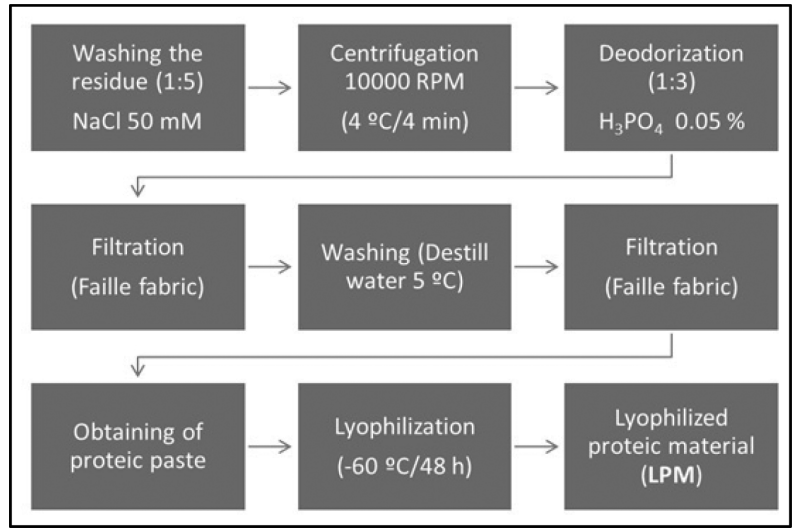

Figure 1. Flowchart of lyophilized myofibrillar proteins obtention from gó whitefish residues. 


\subsection{Characterization of smart biodegradable films}

- Thickness: use of digital micrometer with $0.001 \mathrm{~mm}$ resolution;

- Tensile strength and percent elongation: ASTM D882-91 methodology (ASTM, 1996) using a texturometer (QTS, Brookfield);

- Water vapor permeability: ASTM D882-95 (ASTM, 1995) modified method described by Arfat et al. (2014);

- Solubility: according to Gontard et al. (1994) methodology;

- Color: according to Hernández et al. (2017) methodology. Using MINOLTA colorimeter model CR 310, obtaining $L^{*}$, a* and $b^{*}$ parameters.

\subsection{Evaluation of films $p H$ indicator activity}

$30 \mathrm{~g}$ portions of gó whitefish fillet in natura were placed in glass beakers covered with control (without anthocyanin on formulation) and smart biofilms, and stored under refrigeration $\left(8^{\circ} \mathrm{C}\right)$. Monitoring was done by instrumental color and $\mathrm{pH}$ analysis within 24 hours.

\subsection{Statistical analysis}

The results obtained were evaluated by Analysis of Variance (ANOVA) and Tukey test at $\mathrm{p}<0.05$ significance level, on STATISTICA 7 software.

\section{RESULTS AND DISCUSSION}

\subsection{Characterization of proteic material}

The physico-chemical analysis results of lyophilized myofibrillar protein indicates the efficiency of the process performed, with low values of moisture and lipids and high protein contain (Table 1). The amount of protein obtained is considered relevant because from them will be produced the biofilms.

\subsection{Characterization of biodegradable films}

The films thickness evaluation demonstrates that films with higher anthocyanin content presented higher thickness values (Table 2), as expected, due to total solids content increase by addition of powdered anthocyanin.

All the analyzed films had a significant difference $(p<0.05)$ in relation to the water vapor permeability (WVP), being control film with the highest value and the film with $0.05 \mathrm{~g}$ of anthocyanin the lowest (Table 2). These results indicate that the presence of anthocyanin turned the films less permeable, because the WVP can be affected by several factor of the material, including the additives incorporated in the polymeric matrix. The films also presented a significant difference $(\mathrm{p}<0.05)$ in relation to the solubility, being the control film with the higher value. However, all films presented satisfactory values regarding to this characteristic evaluated. In addition, the films with lower anthocyanin concentrations presented higher values to tensile strength (TS) and percent elongation (E\%), as can be seen in Table 2 .

Table 1. Centesimal composition of lyophilized proteic material.

\begin{tabular}{ll}
\hline Compounds ${ }^{1}(\%)$ & LPM $^{2}$ \\
\hline Moisture & $3.86 \pm 0.1$ \\
Ash & $0.90 \pm 0.4$ \\
Lipids & $2.44 \pm 0.03$ \\
Proteins & $95.01 \pm 0.1$ \\
\hline
\end{tabular}

${ }^{1}$ Results on a dry basis; ${ }^{2}$ Lyophilized proteic material. 
Table 2. Results of thickness, water vapor permeability (WVP), solubility, tensile strength (TS) and percent elongation $(\mathrm{E} \%)$.

\begin{tabular}{llllcr}
\hline Films & $\begin{array}{l}\text { Thickness } \\
(\mathrm{mm})\end{array}$ & $\begin{array}{l}\text { WVP } \\
\left(\times 10^{-11} \mathrm{~g} \cdot \mathrm{m}^{-1} \cdot \mathrm{s}^{-1} \cdot \mathrm{Pa}^{-1}\right)\end{array}$ & $\begin{array}{l}\text { Solubility } \\
(\%)\end{array}$ & $\begin{array}{l}\text { TS } \\
(\mathrm{MPa})\end{array}$ & $\begin{array}{l}\text { E } \\
(\%)\end{array}$ \\
\hline Control & $0.035 \pm 0.02^{\mathrm{d}}$ & $5.23 \pm 0.53^{\mathrm{a}}$ & $36.55 \pm 1.20^{\mathrm{a}}$ & $3.78 \pm 0.63^{\mathrm{d}}$ & $10.4 \pm 1.1^{\mathrm{e}}$ \\
$0.05^{*}$ & $0.038 \pm 0.02^{\mathrm{d}}$ & $3.18 \pm 0.38^{\mathrm{g}}$ & $12.65 \pm 0.05^{\mathrm{e}}$ & $11.93 \pm 0.40$ & $252.65 \pm 0.4^{\mathrm{a}}$ \\
$0.06^{*}$ & $0.041 \pm 0.01^{\mathrm{a}}$ & $3.51 \pm 0.40^{\mathrm{e}}$ & $16.34 \pm 0.07^{\mathrm{d}}$ & $7.07 \pm 0.30^{\mathrm{b}}$ & $111.27 \pm 0.8^{\mathrm{bc}}$ \\
$0.07^{*}$ & $0.042 \pm 0.04^{\mathrm{c}}$ & $3.48 \pm 0.58^{\mathrm{f}}$ & $18.28 \pm 0.04^{\mathrm{d}}$ & $7.84 \pm 0.73^{\mathrm{b}}$ & $111.86 \pm 0.2^{\mathrm{b}}$ \\
$0.08^{*}$ & $0.047 \pm 0.02^{\mathrm{b}}$ & $4.48 \pm 0.30^{\mathrm{c}}$ & $19.04 \pm 0.05^{\mathrm{d}}$ & $4.69 \pm 0.50^{\text {cd }}$ & $109.02 \pm 0.7^{\mathrm{c}}$ \\
$0.09^{*}$ & $0.048 \pm 0.07^{\mathrm{b}}$ & $4.20 \pm 0.36^{\mathrm{d}}$ & $22.76 \pm 0.05^{\mathrm{c}}$ & $4.85 \pm 0.61^{\text {cd }}$ & $105.14 \pm 0.2^{\mathrm{d}}$ \\
$0.1^{*}$ & $0.052 \pm 0.08^{\mathrm{a}}$ & $4.89 \pm 0.42^{\mathrm{b}}$ & $29.55 \pm 0.06^{\mathrm{b}}$ & $8.17 \pm 0.56^{\mathrm{b}}$ & $109.3 \pm 0.7^{\mathrm{bc}}$ \\
\hline
\end{tabular}

*Anthocyanin concentration ( $\mathrm{g} / 100 \mathrm{~g}$ of filmogenic solution); Same letters in the same column did not differ significantly at the level $5 \%(\mathrm{p}<0.05)$.

Table 3. Results of $\mathrm{L}^{*}, \mathrm{a}^{*}$ and $\mathrm{b}^{*}$ color parameters of biodegradable films.

\begin{tabular}{llcr}
\hline Films & $\mathrm{L}^{*}$ & $\mathrm{a}^{*}$ & \multicolumn{1}{c}{$\mathrm{b}^{*}$} \\
\hline Control & $95.54 \pm 0.02^{\mathrm{a}}$ & $-5.46 \pm 0.01^{\mathrm{e}}$ & $8.16 \pm 0.01^{\mathrm{a}}$ \\
$0.05^{* *}$ & $56.94 \pm 0.02^{\mathrm{b}}$ & $25.60 \pm 0.02^{\mathrm{d}}$ & $-6.52 \pm 0.01^{\mathrm{b}}$ \\
$0.06^{* *}$ & $54.95 \pm 0.02^{\mathrm{b}}$ & $27.76 \pm 0.01^{\mathrm{cd}}$ & $-6.83 \pm 0.01^{\mathrm{b}}$ \\
$0.07^{* *}$ & $50.71 \pm 0.01^{\mathrm{c}}$ & $34.4 \pm 0.02^{\mathrm{a}}$ & $-6.94 \pm 0.01^{\mathrm{b}}$ \\
$0.08^{* *}$ & $50.02 \pm 0.03^{\mathrm{c}}$ & $28.43 \pm 0.02^{\mathrm{c}}$ & $-7.03 \pm 0.02^{\mathrm{b}}$ \\
$0.09^{* *}$ & $50.70 \pm 0.02^{\mathrm{c}}$ & $29.36 \pm 0.01^{\mathrm{bc}}$ & $-9.95 \pm 0.02^{\mathrm{c}}$ \\
$0.1^{* *}$ & $46.26 \pm 0.01^{\mathrm{d}}$ & $31.68 \pm 0.02^{\mathrm{ab}}$ & $-8.02 \pm 0.02^{\mathrm{bc}}$ \\
\hline
\end{tabular}

*Color parameters; ** Anthocyanin concentration (g/100 g of filmogenic solution); Same letters in the same column did not differ significantly at the level $5 \%(\mathrm{p}<0.05)$.

The color evaluation indicates that the anthocyanin addition left the films significantly more opaque, as can be observed by the parameter $L^{*}$ decrease (Table 3 ), as expected. Evaluating the results of coordinates $a^{*}$ and $b^{*}$ can be seen the change from greenish to red with the mix of blue tones, due the anthocyanin presence.

According to the found results on biofilms characterization, higher tensile strength, lower WVP and less opaque color, the formulation with lower anthocyanin concentration $(0.05 \mathrm{~g} / 100 \mathrm{~g}$ of filmogenic solution) was selected to evaluate the film application on gó whitefish. It is important to emphasize that all formulations produced could be used to many purposes.

\subsection{Evaluation of smart film as $\mathrm{pH}$ change indicator}

On Table 4, it is possible to see that the biodegradable film added with anthocyanin $\left(0.05 \mathrm{~g} / 100 \mathrm{~g}\right.$ of filmogenic solution), during the fish storage time at $8^{\circ} \mathrm{C}$, presented significant changes on $\mathrm{L}^{*}$ and $\mathrm{a}^{*}$ parameters, according to fish $\mathrm{pH}$ alterations. This result offers a greater safety to the consumer, which can evaluate the food quality and freshness through the package, in this case the smart biofilm, and at the same time avoid the food waste (Pacquit et al. 2006).

The $\mathrm{b}^{*}$ parameter (blue - yellow axis) and the film $\mathrm{pH}$ did not present significant difference over the storage days. Although this parameter did not present a significant difference, the results obtained showed negative values, indicating the presence of the blue component in the film with anthocyanin, that decreased throughout the storage time, due to the volatile bases generated by the fish deterioration, making the medium more alkali. 


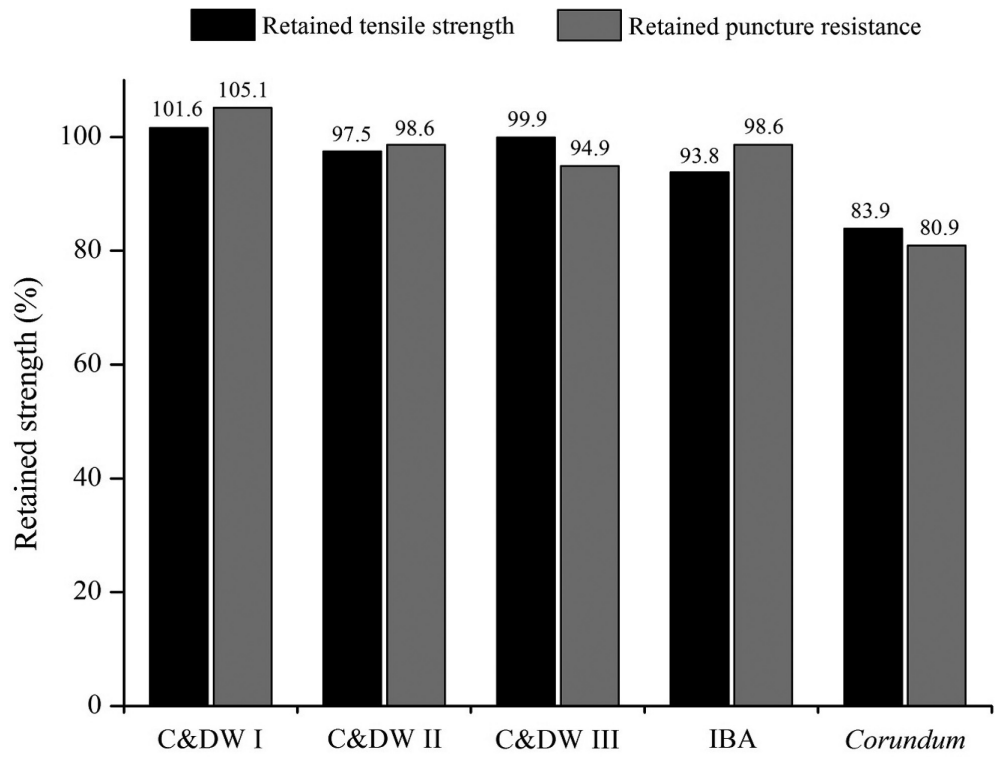

Figure 3. Comparison of the retained strengths of the geotextile after the mechanical damage tests.

aggregates in the short-term behaviour of the geotextile was lower than the damage caused by the standard aggregate used in EN ISO 10722, which opens good perspectives for the use of these type of aggregates in the construction of Civil Engineering infrastructures, allowing their recovery and reuse. However, and before such application, further studies are needed.

\section{ACKNOWLEDGEMENTS}

This work was financially supported by Project POCI-01-0145-FEDER-007457, funded by FEDER funds through "COMPETE 2020 - Programa Operacional Competitividade e Internacionalização" (POCI) and by national funds through "FCT_Fundação para a Ciência e a Tecnologia". J.R. Carneiro would also like to thank "FCT" for the research grant SFRH/ BPD/88730/ 2012 (grant supported by POPH/POCH/FSE funding).

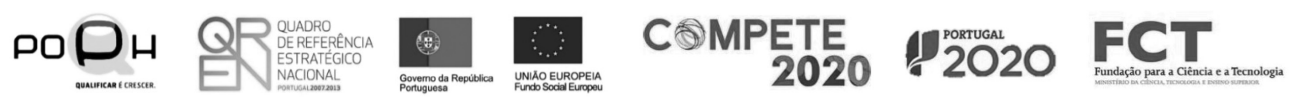

\section{REFERENCES}

EN 933-1. 2012. Tests for geometrical properties of aggregates. Part 1: Determination of particle size distribution - Sieving method.

EN ISO 9862. 2005. Geosynthetics-Sample and preparation of test specimens.

EN ISO 10319. 2008. Geosynthetics-Wide-width tensile test.

EN ISO 10722. 2007. Geosynthetics-Index test procedure for the evaluation of mechanical damage under repeated loading. Damage caused by granular material.

EN ISO 12236. 2006. Geosynthetics-Static puncture test (CBR test).

Montgomery, D.C. \& Runger, G.C. 2010. Applied Statistics and Probability for Engineers. 5th ed. New York: John Wiley \& Sons.

Pinho-Lopes, M.J.F. \& Lopes, M.L. 2010. Durability of Geosynthetics. Porto: FEUP (in Portuguese).

Vieira, C.S. \& Pereira, P.M. 2016. Interface shear properties of geosynthetics and construction and demolition waste from large-scale direct shear tests. Geosynthetics International 23 (1): 62-70.

Vieira, C.S., Pereira, P.M. \& Lopes, M.L. 2016. Recycled construction and demolition wastes as filling material for geosynthetics reinforced structures. Interface properties. Journal of Cleaner Production 124: 299-311. 
Bridle, P., Timberlake, C.F. 1997. Anthocyanins as natural food colours - selected aspects. Food Chemistry 58 (1-2): 103-109.

Dangaran, K., Tomasula, P.M., QI, P. 2009. Structure and function of protein-based edible films and coatings. In: Embuscado, M.E., Kerry C., Huber, K.C. (Eds.). Edible Films and Coatings for Food Applications. New York: Springer.

Davanço, T., Tanada-Palmu, P., Grosso, C. 2007. Filmes compostos de gelatina, triacetina, ácido esteárico ou capróico: efeito do $\mathrm{pH}$ e da adição de surfactantes sobre a funcionalidade dos filmes. Ciência e Tecnologia de Alimentos. Campinas. 27 (2): 408-416.

Gonçalves, A.A. 2011. Tecnologia do Pescado: Ciência, Tecnologia, Inovação e Legislação. São Paulo: Atheneu.

Gontard, N., Duchez, C., Cuq, J., Guilbert, S. 1994. Edible composite films of wheat gluten and lipids: Water vapor permeability and other physical properties. International Journal Food Science Technology. Oxford. 29 (1): 39-50.

González, K., Martin, L., González, A., Retegi, A., Eceiza, A., Gabilondo, N. 2017. D-isosorbide and 1,3-propanediol as plasticizers for starch-based films: Characterization and aging study. Journal of Applied Polymer Science 134 (20): 1-10.

Hernández, E.J.G.P., de Carvalho, R.N., Joele, M.R.S.P., da Silva Araújo, C., \& Lourenço, L.D.F.H. (2017). Effects of modified atmosphere packing over the shelf life of sous vide from captive pirarucu (Arapaima gigas). Innovative Food Science \& Emerging Technologies 39: 94-100.

Iwata, K., Ishizaki, S., Handa, A., Tanaka, M. 2000. Preparation and characterization of edible films from fish water-soluble proteins. Fisheries Science. Tokyo. 66 (2): 372-378.

Khwaldia, K., Arab-Tehrany, E., Desobry, S. 2010. Biopolymer coatings on paper packaging materials. Comprehensive Reviews in Food Science and Food Safety. Chicago. 9 (1): 82-91.

Limpan, N., Prodpran, T., Benjakul, S., Prasarpran, S. 2010. Properties of biodegradable blend films based on fish myofibrillar protein and polyvinyl alcohol as influenced by blend composition and $\mathrm{pH}$ level. Journal Food Engineering. Essex. 100 (1): 85-92.

Lopes, T.J., Xavier, M.F., QUadri, M.G.N., QuadrI, M.B. 2007. Anthocyanins: A Brief Review of Structural Characteristics and Stability. Departamento de Engenharia Química e Engenharia de Alimentos - CPGENQ-UFSC.

Luchese, C.L., Sperotto, N., Spada, J.C., Tessaro, I.C. 2017. Effect of blueberry agro-industrial waste addition to corn starch-based films for the production of a $\mathrm{pH}$-indicator film. International journal of biological macromolecules 104: 11-18.

Pacquit A., Frisby J., Diamond D., Lau K., Farrell A., Quilty B., Diamond D. 2006. Development of a smart packaging for the monitoring of fish spoilage. Food Chemistry 102: 466-470.

Paschoalick, T.M., Garcia, F.T., Sobral, P.J.A., Habitante, A.M.Q.B. 2003. Characterization of some functional properties of edible films based on muscle proteins of Nile tilapia. Food Hydrocolloids. Oxford. 17 (4): 419-427.

Rebello, F.F.P. 2009. Novas tecnologias aplicadas às embalagens de alimentos-Revisão. Revista Agroambiental. Instituto Federal Sul de Minas.

Shiku, Y., Hamaguchi, P., Tanaka, M. 2003. Effect of pH on the preparation of edible films based on fish myofibrillar proteins. Fisheries Science. Tokyo. 69 (5): 1026-1032.

Shiku, Y., Hamaguchi, P., Benjakul, S., Visessanguan, W., Tanaka M. 2004. Effect of surimi quality on properties of edible films based on Alaska pollack. Food Chem 86 (4): 493-499.

Souza, S.M.A., Sobral, P.J.A., Menegalli, F.C. 2012. Physical properties of edible films based on bovine myofibril proteins. Seminário: Ciências Agrárias. 33: 283-296.

Yoshida, C.M.P., Maciel, V.B.V., Mendonça, M.E.D., Franco, T.T. 2014. Chitosan biobased and intelligent films: Monitoring $\mathrm{pH}$ variations. LWT_Food Science and Technology 55: 83-89. 